\title{
Relationship between Serum 25(OH)D Levels and Blood Pressure in Children with Nephrotic Syndrome
}

\author{
Rosmayanti Syafriani Siregar, Oke Rina Ramayani*, Winson Chitra, Rafita Ramayati \\ Department of Pediatric, Medical Faculty, University Sumatera Utara, Medan, Indonesia
}

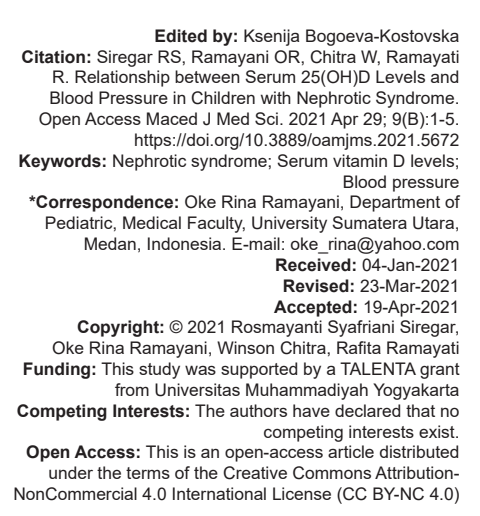

Introduction

Nephrotic syndrome (NS) is one of the most common kidney disorders in children. The incidence of NS in children in the United States of America and the United Kingdom is 2-7 newly diagnosed cases per 100,000 children annually, with a prevalence of 12-16 cases per 100,000 children [1], [2]. Incidence of NS is higher in developing countries. In Indonesia, it is reported that 6 per 100,000 children annually, aged $<14$ years old, with boy compared to the girl is 2: 1 [3].

Complications of NS are divided into two main entities, which are complications related to the disease and complications related to therapy. Complications related to the disease compose of infections (peritonitis, sepsis, and cellulitis), thromboembolic (vein thromboembolic and pulmonary emboli), hypovolemic crisis (abdominal pain, tachycardia, and hypotension), cardiovascular disorders (hyperlipidemia), renal failure, and others like hypothyroid, and hypocalcemia. One of the etiologies of hypocalcemia is related to Vitamin D metabolism abnormality [1].

Studies in the United States, Canada, and Europe showed that $20-100 \%$ of the geriatric population suffers from Vitamin D deficiency and approximately 1 billion population all over the world has either Vitamin $D$ deficiency or insufficiency [4]. Southeast Asian Nutrition Surveys (SEANUT) in Indonesia, Malaysia, Thailand, and Vietnam in 2016 showed in Indonesia, only 5\% of children with an adequate $25(\mathrm{OH}) \mathrm{D}$ levels (serum levels $>30 \mathrm{ng} / \mathrm{mL}$ ) [5].

A previous study showed that $93 \%$ of children with NS have Vitamin D deficiency, while $86 \%$ with moderate to severe levels of severity [6]. One active form of Vitamin D, calcitriol, is known as an important factor in regulating the angiotensin-renin system which plays an important role in hypertension. Therefore, normal levels of calcitriol not only benefit in maintaining calcium homeostasis but also electrolytes, hormonal, and blood pressure homeostasis [7].

Astudy in mice reported that Vitamin D significantly suppresses the renin expression gene through the binding process of transcription factor cAMP response elementbinding protein (CREB) hence suppress the mechanism of action CREB in the renin promoter gene [8]. As far as our concern, there are many studies regarding Vitamin $\mathrm{D}$ deficiency in children with NS, yet study regarding the association between Vitamin D level and blood pressure in children with NS has never been reported. 


\section{Methods}

This was a cross-sectional, observational analytic study to evaluate the association of serum 25(OH)D level with blood pressure in children with NS. This study was done at Pediatric Outpatient Department and Inpatient Department H. Adam Malik Hospital, Medan, February-August 2019.

Inclusion criteria were children NS with minimal change disease who came to Pediatric Outpatient Department or were admitted to Inpatient Department H. Adam Malik Hospital and not consumption ACE inhibitor (as agent to reduce proteinuria) minimally for 6 weeks. Exclusion criteria were severely malnourished NS, had liver disease, had malabsorption diseases like short bowel syndrome, and those who refused to perform blood examination or not sign-in the informed consent.

Data collection of demographic characteristics, history of illness with diagnosis, and severity of proteinuria were collected from previously diagnosed children with NS. Parents were subsequently explained regarding the study and asked to fill and sign the informed consent. Afterward, physical examination including anthropometric measurements was done. Blood pressure measurement was done when child is seated, with a sphygmomanometer and adjusted blood cuff measurement. Blood pressure examination was done 3 times with 15 min intervals. Mean blood systolic and diastolic pressure values were then measured.

Criteria for blood pressure were done based on the National High Blood Pressure Education Program (NHBPEP) [9]. According to NHBPEP, prehypertension is defined as an average systolic and diastolic blood pressure level that is in $90^{\text {th }}$ percentile to below $95^{\text {th }}$ percentile based on sex, height, and age. In this study, we divided the ages as preadolescent and adolescent, whereas blood pressure elevation in adolescent may be the first clue to underlying renal pathology, or it may be simply a warning sign of future cardiovascular risk.

Venipuncture for $5 \mathrm{ml}$ of venous blood was done for measurements of serum creatinine, albumin, calcium, and 25(OH)D levels. Examination for serum $25(\mathrm{OH}) \mathrm{D}$ levels was done by enzyme-linked immunoassay with Mini Vida Brahms ${ }^{\circledR}$.

Spearman correlation test was analyzed for data which were not normally distributed by SPSS Statistics ver. 20.0. Shapiro-Wilk test was performed to test data distribution. Statistical significance was considered at $\mathrm{P}<0.05$ with a confidence interval of $95 \%$. This study was approved by the Health Research Ethical Committee, Medical Faculty of University of Sumatera Utara/Haji Adam Malik General Hospital, Medan, North Sumatera number 367/TGL/KEPK FK USU-RSUP HAM/2019.

\section{Results}

During the study period, there were 35 children with NS included (Table 1), with a median of age 12 years old. The youngest subject enrolled in this study was 2 years old. Sixty percent of the subjects had nephrotic proteinuria. The mean value of serum calcium levels was $7.9 \pm 1.0 \mathrm{mg} / \mathrm{dl}$ and the mean value of serum $25(\mathrm{OH}) \mathrm{D}$ levels was $7.9(0.7-37.8)$ $\mathrm{ng} / \mathrm{ml}$. Only $20 \%$ of the subject had a normal value of serum $25(\mathrm{OH}) \mathrm{D}$ levels, while the others had low serum 25(OH)D levels.

Table 1: Subjects characteristics

\begin{tabular}{ll}
\hline Characteristics & $\mathrm{n}=35$ \\
\hline Median of age, year (range) & $12.0(2.0-17.0)$ \\
Sex, $\mathrm{n}(\%)$ & \\
$\quad$ Male & $23(65.7 \%)$ \\
Female & $12(34.3 \%)$ \\
Mean of height, cm (SD) & $132.7(25.5)$ \\
Median BMl, $\mathrm{kg} / \mathrm{m}^{2}$ (range) & $19.0(12.6-59.3)$ \\
Median creatinine levels, mg/dl (range) & $0.4(0.2-2.2)$ \\
Mean glomerular filtration rate, ml/min/1.73m ${ }^{2}$ (SD) & $136.9(52.7)$ \\
Median albumin levels, g/dl (range) & $2.6(0.9-5.3)$ \\
Proteinuria, $\mathrm{n}(\%)$ & \\
Nephrotic & $21(60.0)$ \\
Non-nephrotic & $14(40.0)$ \\
Mean calcium serum levels, mg/dl (SD) & $7.9(1.0)$ \\
Median systolic blood pressure (range) & $110.0(90.0-160.0)$ \\
Median diastolic blood pressure (range) & $70.0(60.0-100.0)$ \\
Median Vitamin D serum levels, $\mathrm{ng} / \mathrm{ml}$ (range) & $7.9(0.7-37.8)$ \\
Category of vitamin D status, $\mathrm{n}(\%)$ & $7(20.0)$ \\
Normal & $2(5.7)$ \\
Insufficiency & $14(40.0)$ \\
Deficiency & $12(34.3)$ \\
Severe deficiency & \\
\hline
\end{tabular}

The median serum 25(OH)D (Vitamin D) levels were not significantly different among age group categories (Table 2). Association between serum Vitamin $D$ levels with proteinuria category showed there was a significant association, whereas the subjects with nephrotic proteinuria showed lower serum Vitamin D levels compared to subjects with non-nephrotic proteinuria (Table 3 ).

Table 2: Serum Vitamin D levels based on age group category

\begin{tabular}{lll}
\hline Age group category & Median serum Vitamin D levels, $\mathrm{ng} / \mathrm{ml}$ (range) & $\mathrm{p}^{\text {a }}$ \\
\hline$<5$ years old & $8.6(2.0-20.9)$ & 0.784 \\
$5-10$ years old & $8.7(0.8-37.8)$ & \\
$>10$ years old & $7.7(0.7-27.3)$ & \\
\hline${ }^{\text {a } K r u s k a l-W a l l i s ~ t e s t . ~}$ & &
\end{tabular}

Figures 1 and 2 showed about correlation between SBP and DBP in preadolescent compared with reference standard for prehypertension based on NHBPEP also for adolescent (Figures 3 and 4).

Table 3: Association of proteinuria with serum Vitamin D levels

\begin{tabular}{|c|c|c|c|}
\hline & \multicolumn{2}{|l|}{ Proteinuria category } & \multirow[t]{2}{*}{$p^{a}$} \\
\hline & Nephrotic & Non-nephrotic & \\
\hline $\begin{array}{l}\text { Median serum Vitamin D } \\
\text { levels, } \mathrm{ng} / \mathrm{ml} \text { (range) }\end{array}$ & $4.9(0.7-15.0)$ & $18.4(3.6-37.8)$ & $<0.001^{*}$ \\
\hline $\begin{array}{l}\text { Median systolic blood } \\
\text { pressure, } \mathrm{mmHg} \text { (range) }\end{array}$ & $110.0(90.0-160.0)$ & $100.0(90.0-160.0)$ & $0.039^{*}$ \\
\hline $\begin{array}{l}\text { Median diastolic blood } \\
\text { pressure, } \mathrm{mmHg} \text { (range) }\end{array}$ & $80.0(60.0-100.0)$ & $70.0(60.0-100.0)$ & $0.036^{*}$ \\
\hline
\end{tabular}
a

There was also a significant correlation between proteinuria and the systolic and diastolic blood 


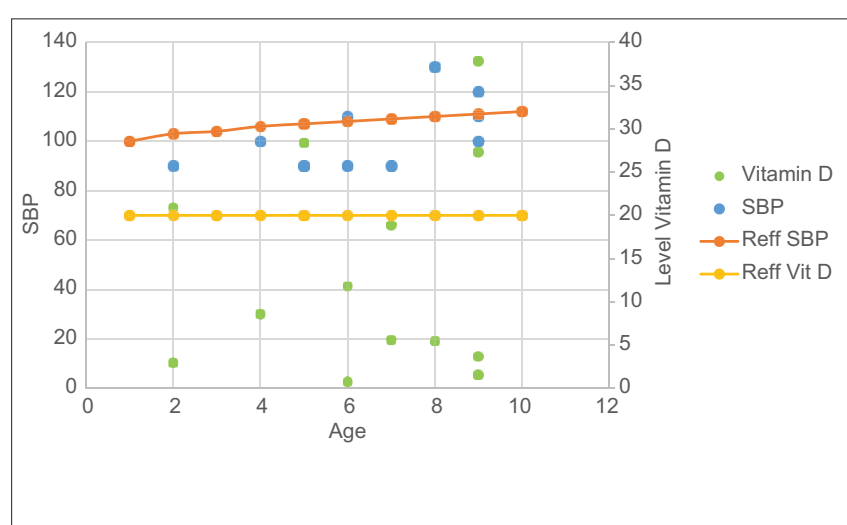

Figure 1: Relationship between systolic blood pressure, level Vitamin $D$, and age in preadolescent.

pressure, whereas there was an elevation of systolic and diastolic blood pressure in subjects with nephrotic proteinuria compared to their non-nephrotic proteinuria counterparts (Table 4). Correlation of serum Vitamin D levels with systolic and diastolic blood pressure showed a weak negative correlation in preadolescent and adolescent (Figures 1 and 3 ).

\section{Discussion}

This was a hospital-based analytic descriptive, cross-sectional study done from February to August 2019. In this study, we examined the serum Vitamin D levels, proteinuria category, and investigated the association with blood pressure in previously diagnosed children NS with minimal change disease. In this study, the levels of Vitamin $D$ in patients with proteinuria with nephrotic range were lower than those with SN patients with non-nephrotic range proteinuria; this indicates a loss of Vitamin $D$ binding protein through urine in patients with NS.

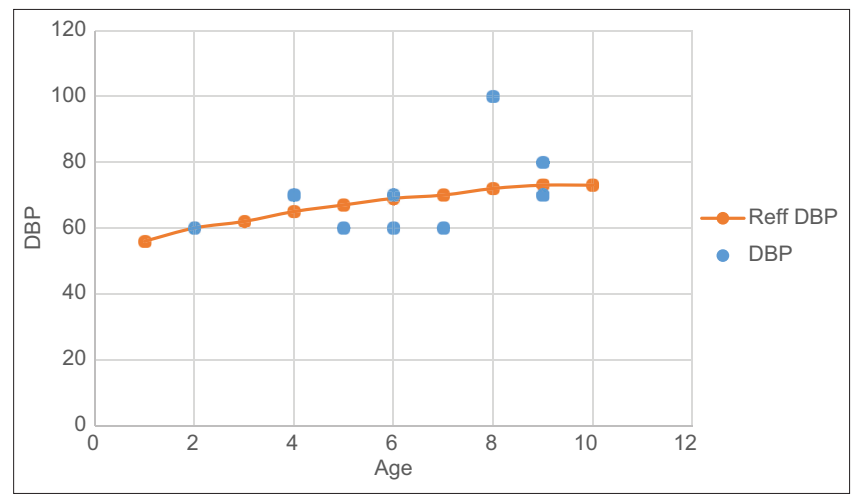

Figure 2: Relationship between diastolic blood pressure and age in preadolescent.

Low levels of Vitamin D are associated with elevated blood pressure. There are a number of plausible physiological mechanisms for this association. Vitamin $D$ deficiency may be linked to the pathophysiology of hypertension through its influence on the renin-angiotensin system (RAAS). Low level Vitamin D may result in upregulation RAAS. Several studies have shown that low Vitamin D levels affect RAAS activation, through decreased renin gene expression and increased Angiotensin II activity [10], [11].

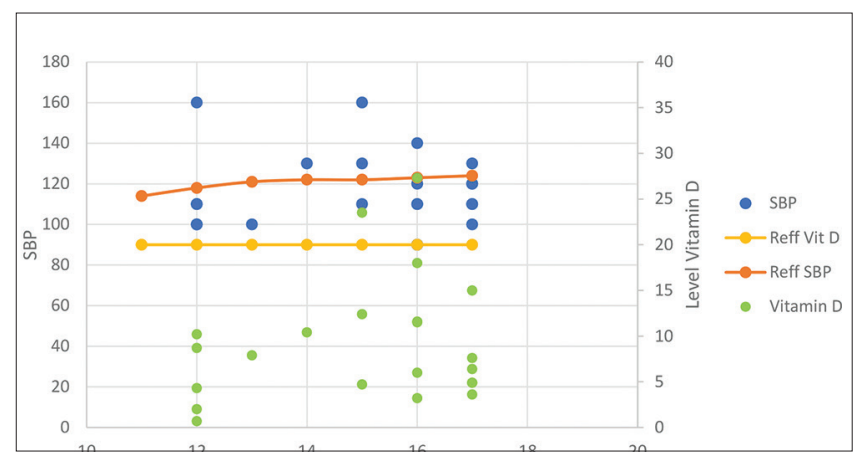

Figure 3: Relationship between systolic blood pressure, level Vitamin $D$, and age in adolescent.

The positive association between $25(\mathrm{OH})$ $D$ levels and flow mediated arterial vasodilatation in chronic kidney disease patients has long been described [12]. Other evidence in animal studies has found that the inactivity of Vitamin D causes decreased expression of endothelial nitric oxide synthase resulting in increased arterial stiffness [13]. Vitamin D also plays an important role to inhibit lipogenesis and stimulate lipolysis; therefore, it has beneficial effect in reducing the risk of calcification in the blood vessels [14].

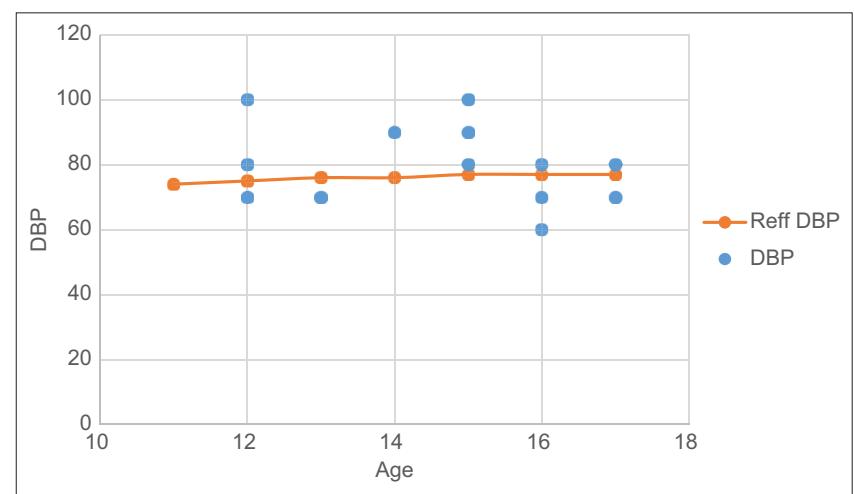

Figure 4: Relationship between diastolic blood pressure and age in adolescent.

In our study, serum Vitamin D levels have been shown to have a weak negative correlation with blood pressure. If we analyze further in Figures 1 and 3 , more adolescents have low Vitamin D levels, and their Vitamin $D$ levels are also lower than pre adolescents. Our result is not contradictive with another study by Forman et al. that found individuals with deficiency Vitamin D had increased plasma angiotensin II [11]. These data suggest that low Vitamin D levels can lead to upregulation of the renin angiotensin system.

Table 4: Correlation of serum Vitamin D levels and blood pressure

\begin{tabular}{lllll}
\hline & Median & Range & $\mathrm{r}$ & $\mathrm{p}^{\mathrm{a}}$ \\
\hline Serum Vitamin D levels, $\mathrm{ng} / \mathrm{ml}$ & 7.9 & $0.7-37.8$ & -0.114 & 0.513 \\
Systolic blood pressure, $\mathrm{mmHg}$ & 110.0 & $90.0-160.0$ & & \\
Serum Vitamin D levels, $\mathrm{ng} / \mathrm{ml}$ & 7.9 & $0.7-37.8$ & -0.174 & 0.317 \\
Diastolic blood pressure, $\mathrm{mmHg}$ & 70.0 & $60.0-100.0$ & & \\
\hline${ }^{\mathrm{a}}$ Spearman correlation test. & & & &
\end{tabular}


Twenty percent of subjects in this study have normal serum Vitamin $D$ levels, while others have a deficiency with severe deficiency category of $34.3 \%$ Solanski et al. in India showed that $82 \%$ of children with NS have serum Vitamin D deficiency and $47 \%$ of them are severe deficiency [15]. Similar results were also observed by lllalu et al. that showed $20 \%$ of subjects with NS have normal serum Vitamin D levels and the others have deficiency and sufficiency of $47 \%$ and $32 \%$, respectively [16].

This study shows significant association between serum Vitamin $D$ levels and proteinuria, whereas subjects with nephrotic proteinuria have lower serum Vitamin D levels to those who are nonnephrotic proteinuria. Similar mechanism occurred due to excretion of Vitamin $D$ binding protein through urine. This study is in line with study by Gayk et al. that showed lower serum Vitamin D levels on NS patients compared to their non-proteinuric controls [17]. Low serum Vitamin $D$ levels are due to the excretion of Vitamin D-binding proteins in the urine with or without decreased production of $25(\mathrm{OH}) \mathrm{D}$ by the kidneys [18].

Another study from Doorenbos 2012 showed that urinary Vitamin $D$ binding protein is not associated with level plasma Vitamin $D$ except for severe NS. Hence, another possibility that influence level plasma Vitamin D is dietary intake of Vitamin $D$ and sun exposure [19]. In countries with four seasons, adolescent is more aware of the effects of sun exposure than preadolescent so that it can affect vitamin D levels. However, in a tropical country like Indonesia, sun exposure becomes less significant with changes in their Vitamin D levels.

Vitamin $D$ has a role in progression renal damage, as Vitamin $D$ could have antiproteinuric effect. Szeto et al. described calcitriol (activated Vitamin $D$ hormone) could decrease proteinuria in ten patients with IgA nephropathy [20]. Similar to minimal change disease, Vitamin D could have effect antiproteinuric combined with angiotensin converting enzyme inhibitor. In our study, we did not consider duration of illness which is about the time since the child was first diagnosed with NS. Hence, the role of Vitamin D as an antiproteinuric, in this study, could not be explained well.

\section{Conclusions}

Both Vitamin D deficiency and severe deficiency are observed in children with NS. Serum Vitamin D levels have been shown to have a weak negative correlation with blood pressure in children with NS.

\section{Acknowledgment}

This research was supported by TALENTA Universitas Sumatera Utara grant number: 4167/ UN5.1.R/PPM/2019 in 1 April 2019. I would like to thank my research partner, Head of Nephrology Paediatric Division, and Chief of Paediatric Department who had helped us in defining the path of my research. For this, I am extremely grateful.

\section{References}

1. Park SJ, Shin JI. Complication of nephrotic syndrome. Korean J Pediatr. 2011;54(8):322-8.

PMid:22087198

2. Eddy AA, Symons JM. Nephrotic syndrome in childhood Lancet.2003;362(9384):629-39. https://doi.org/10.1016/ s0140-6736(03)14184-0

PMid:12944064

3. Wila WIGN. Penelitian Beberapa Aspek Klinis dan Patologi Anatomis Sindrom Nefrotik Primer Pada Anak di Indonesia. Jakarta: Disertasi, FKUl; 1992. https://doi.org/10.14238/ sp15.3.2013.133-6

4. DeLuca HF, Sempos CT, Heijboer AC, Bikle DD, Bollerslev J, Bouillon $R$, et al. Vitamin $D$ assays and the definition of hypovitaminosis D: Results from the First International Conference on Controversies in Vitamin D. Br J Clin Pharmacol. 2018;84(10):2194-207. https://doi.org/10.1111/bcp.13652 PMid:29851137

5. Poh BK, Rojroongwasinkul N, Nguyen BK, Sandjaja, Ruzita AT, Yamborisut $\mathrm{U}$, et al. 25-hydroxy-vitamin $\mathrm{D}$ demography and the risk of Vitamin D insuffiency in the South East Asian Nutrition Surveys (SEANUTS). Asia Pac Clin Nutr 2016;25(3):538-48. PMid:27440689

6. Nielsen CA, Jensen JE, Cortes D. Vitamin D status is insufficien in the majority at diagnosis of nephrotic syndrome. Dan Med J. 2015;62(2):A5017.

PMid:25634505

7. Fanari Z, Hamami S, Hammami MB, Hammami S, Abdellatif A. Vitamin $D$ deficiency plays an important role in cardiac disease and affects patient outcome: Still a myth or a fact that needs exploration? J Saudi Heart Assoc. 2015;27(4):264-71. https:// doi.org/10.1016/j.jsha.2015.02.003

PMid:26557744

8. Yuan W, Pan W, Kong K, Zheng W, Szeto FL, Wong KE, et al. 1.25 dihydroxyvitamin D3 suppressesrenin gene transcription by blocking the activity of the cyclic AMP response element in the renin gene promoter. J Biol Chem. 2007;282(41):29821-30. https://doi.org/10.1074/jbc.m705495200

PMid:17690094

9. National High Blood Pressure Education Program Working Group on High Blood Pressure in Children and Adolescents. The $4^{\text {th }}$ Report on the Diagnosis, Evaluation, and Treatment of High Blood Pressure in Children and Adolescents, NIH; 2005. https://doi.org/10.1542/peds.114.2.s2.555

10. LiY,KongJ,WeiM,ChenZF, LiuSQ, CaoLP.1,25Dihydroxyvitamin D3 is a negative endocrine regulator of the renin-angiotensin system. J Clin Invest. 2002;110(2):229-38. https://doi. 


\section{org/10.1172/jci0215219 \\ PMid:12122115}

11. Forman JP, Williams JS, Fisher ND. Plasma 25-hydroxyvitamin D and regulation of the renin-angiotensin system in humans. Hypertension. 2010;55(5):1283-8. https://doi.org/10.1161/ hypertensionaha.109.148619

PMid:20351344

12. Jeong HY, Park KM, Lee MJ, Yang DH, Kim SH, Lee SY. Vitamin D and hypertension. Electrolyte Blood Press. 2017;15(1):1-11. PMid:29042901

13. Andrukhova O, Slavic S, Zeitz U, Riesen SC, Heppelmann MS, Ambrisko TD, et al. Vitamin D is a regulator of endothelial nitric oxide synthase and arterial stiffness in mice. Mol Endocrinol. 2014;28(1):53-64. https://doi.org/10.1210/me.2013-1252 PMid:24284821

14. Shi H, Norman AW, Okamura WH, Sen A, Zernel MB. 1 alpha, 5 dyhydrovitamin D3 modulates human adipocyte metabolism via non-genomic action. FASEB J. 2001;(14):2751-3. https://doi. org/10.1096/fj.01-0584fje

PMid:11606486

15. Solanski JR, Shruthy S, Kalpita SS. Prevalence of Vitamin D3 deficiency among pediatric patient with idiophaticnephrotic syndrome in remission a cross sectional observational study from Vododara, Gujarat. Indian J Child Health. 2018;5(7):481-3. https://doi.org/10.32677/ijch.2018.v05.i07.007

16. Illalu S, Velagala SV, Sudhindrashayana R. Study of prevalence of Vitamin D deficiency in nephrotic syndrome. Int J Contemp Pediatr. 2019;6(2):288-94. https://doi.org/10.18203 / 23493291.ijcp20190502

17. Schmidt-Gayk H, Grawunder C, Tschope W, Schmitt W, Ritz E, Pietsch V. 25-hydroxy-Vitamin-D in nephrotic syndrome. Lancet. 1977;2(8029):105-8. https://doi.org/10.1016/ s0140-6736(77)90118-0

PMid:69193

18. Goldstein DA, Haldiman B, Sherman D, Norman AW, Massry SG. Vitamin D metabolite and calcium metabolism in patients with nephrotic syndrome and normal renal function. J Endocrinol Metabol. 1981;52(1):116-22. https://doi. org/10.1210/jcem-52-1-116

PMid:6969729

19. Doorenbos CR, Milton M, Vogt L, Kema IP, van den Born J, Gans RO, et al. Antiproteinuric treatment reduces urinary loss of Vitamin D-binding protein but does not affect Vitamin D status in patients with chronic kidney disease. J Steroid Biochem Mol Biol. 2012;128(1-2):56-61. https://doi.org/10.1016/j. jsbmb.2011.09.002

PMid:21958677

20. Szeto CC, Chow KM, Kwan BC, Chung KY, Leung CB, Li PK. Oral calcitriol for the treatment of persistent proteinuria in immunoglobulin A nephropathy: An uncontrolled trial. Am J Kidney Dis. 2008;51(5):724-31. https://doi.org/10.1053/j. ajkd.2007.12.038

PMid:18436082 